\title{
みかん缶詰中のメチルセルロースの定量
}

四方田干佳子* ・豊田正武* ・伊藤誉志男*・原田基夫*

\section{Determination of Methyl Cellulose in Canned Mandalin Oranges}

\author{
Chikako Yомота*, Masatake Toyoda*, Yoshio Ito*, Motoo Harada* \\ * National Institute of Hygienic Sciences, Osaka Branch; \\ 1-1-43, Hoenzaka, Higashi-ku, Osaka 540
}

\begin{abstract}
A determination method of methyl cellulose (MC) from canned mandalin oranges was developed by using semimicro Zeisel apparatus and gas chromatography. $\mathrm{MC}$ was extracted from $25 \mathrm{~g}$ of sample with water and the solution was dialyzed against water for 2 hours. The inner solution was evapolated to $3 \mathrm{ml}$, and passed through the gel permeation chromatographic column (Toyopearl HW-60F, $1.5 \times 30 \mathrm{~cm}$ ) by water in order to remove the low molecular weight substances which have the methoxyl groups. The fraction containing $\mathrm{MC}$ was condensed to $1 \mathrm{ml}$ and transfered into semimicro Zeisel apparatus to decompose of MC. The methyl iodide caught in ethyl acetate was determined by gas chromatography equipped with a flame ionization detecter. The recovery of MC at the level of $0.1 \%$ was $86 \%$. MC contents in eleven samples of commercial canned mandalin oranges was determined, three samples in which contained $0.0008-0.0015 \%$.

(Received Jul. 17, 1984)
\end{abstract}

メチルセルロース (MC) はセルロースのメチルエー テルで， 従来食品添加物としてメトキシル基含量 26〜 33\%のあのか，乳化剂, 安定剤, 保水剂等として用いら れてきた。しかし，現在は大部分か建築工業における壁 剤, 化粧品工業でのシャンブー等に使用されて括り, 食 品ではわずかにみかんの午詰などに用いられているにす ぎない。すなわら， みかんの年詰の場合，MC は白濁防 止剂として $0.001 〜 0.002 \%$ 添加され，これは $\mathrm{MC}$ を安 定剤として用いた場合の $0.05 〜 0.07 \%$ よかなり低い 値である1。

MCの定量法としては“食品中の食品添加物分析法”2) にセミミクロ Zeisel 装监及びガスクロマトグラフィー を用いる方法が記載されているが，みかんの午詰中の MC の定量法については詳細に榆討されていない。又, MC を酸加水分解後，糖のガスクロマトグラフィーを行 った例名 むあるが，メトキシルの置寏度が不均一である ため多くのピークが見られ，定量に用いることは困難で あると考えられる。

本報では，前処理としてゲルパーミィエイションクロ マトクラフィー（GPC）を用いて妨害物質除去後，MC
をZeisel 装置により分解し，生成したヨウ化ィチルを ガスクロマトクラフィーで定量することにより，みかん の午詰中の MC の定量が可能となったので報告する。

\section{実 験 方 法}

\section{1. 試薬・試料}

メチルセルロースは信越化学(株) 製 SM-100 (メトキ シル基 27.5〜31.5\%) を用いた。その他の試薬はすべ て市販の特級品を用いた。

ゲルパーミィエイションクロマトグラフィー (GPC)

用ゲルとして Toyopearl HW-60F を用いた。

赤リン熙䖲液：赤リン $1 \mathrm{~g}$ を水 $100 \mathrm{~m} l$ に㦟濁させた。 みかん午詰 11 検体は市場より購入して用いた。

\section{2. 試料の調製}

みかん乍詰の内容物をすべてミキサーで 1 分間均質化 し, その $25 \mathrm{~g}$ を採り水 $40 \mathrm{~m} l$ 及びセライト $1 \mathrm{~g}$ を加 えてょく振とうした後遠心分離する。上澄液を取り，同 様の操作をるら一度線り返し上澄液は合わせて透析千= ーブに入れ $1 l$ の水に対して 2 時間透析した。この内液 を沪紙，ついで $3.0 \mu \mathrm{m}$ のメンブランフィルターにより

* 国立衛生試験所大阪支所（广 540 大阪市東区法円坂 1-1-43） 
沪過し不容物を除いてから，約 $3 \mathrm{~m} l$ となるまで減俚濃 樎した。この夜を Toyopearl HW-60F カラム $(1.5 \times$ $30 \mathrm{~cm})$ による $\mathrm{GPC}$ にかけ，木で溶出させて $3.3 \mathrm{ml}$ ずつ分取した。フラクション7〜9を㐮䈹して $1 \mathrm{ml}$ し試料とした。

3. セミミクロ Zeisel 装置による MC の分解

セミミクロZeisel 装置は既法"゙に徒い作製したものを 用いた。分解フラスコに，調製した試料，ヨウ化水素酸 $8 \mathrm{ml}$, 沸滕石を入れ, 窒素ガスを通じながら $160^{\circ} \mathrm{C}$ の油 浴により加熱した。発生するョウ化メチルは赤リン㗭濁 液を通して洗浄し，ドライフイスノメタノール洽却下で 酢酸エチル $8 \mathrm{~m} l$ により捕集した。得られた捕集液は酢 酸エチルにより $10 \mathrm{ml}$ の定容とした。

4. ガスクロマトグラフィー (GC)

得られた酶酸エチル容夜中のヨウ化メチルを GCによ り定量した。ガスクロマトグラフは柳本製作所（株）の G80 型水素炎イオン化検出器付を用い，カラムは chromosorb 101 (mesh 60〜80)，3.3×1.5 m を用いた。

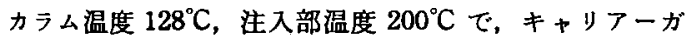
スは窒素とし流速 $15 \mathrm{ml} /$ 分で測定した。

\section{結果}

1. ガスクロマトグラフィー (GC) における溶媒の険 討

GC 測定用の溶媒を検討したところ, ェーテル，フセ トン, へキサンは溶媒ピークとヨウ化メチルのピークが 重なるため不適当で，酶酸ブチル，トルエンは容媒ピー クの tailing が大きく定量に 30 分以上を要した。酢酸 エチルはヨウ化メチルのピークとの分離む良好で tailing 小さかった。従って, ヨウ化メチルの捕集溶媒と して醧酸エチルを用いることとした。

\section{2. メチルセルロースの GC 及び検是線の作成}

メチルセルロース (MC) $1 \mathrm{mg}$ を試料として, Zeisel 装置で分解した時の GCチャートを Fig. 1 に示した。 生じたヨゥ化メチルの保持時間は 3.8 分であった。

次に MC を標準として GC 用検量線を作成したとこ ろ，Fig. 2 に示すよらに良好な直線関保が得られた。

3. MCのゲルパーミィエイションクロマトグラフィ - (GPC)

みかんには MC 以外のメトキシル基を含む妨害物質 が含まれることが知られている。そこで GPCにより妨 害物と MC の分離を試みた。Fig. 3 に Toyopearl HW60F カラムによる MC の溶出パターンを示した。各フ ラクションの MC の定量はフンスロン硫酸法”により

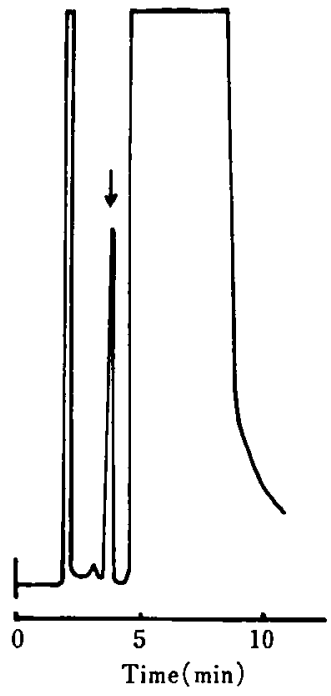

Fig. 1 Gas chromatograms of methyl iodide An arrow indicate the peak of methyl iodide

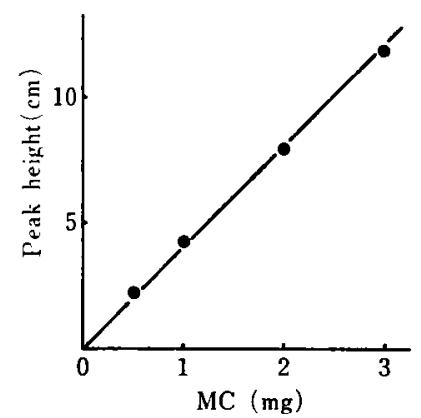

Fig. 2 Calibration curve of methyl cellulose (MC)

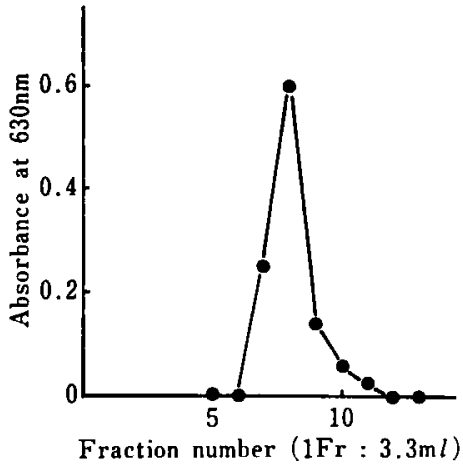

Fig. 3 Elution pattern of MC in gel permeation chromatography by using Toyopearl HW $-60 \mathrm{~F}$ column $(1.5 \times 30 \mathrm{~cm})$ 

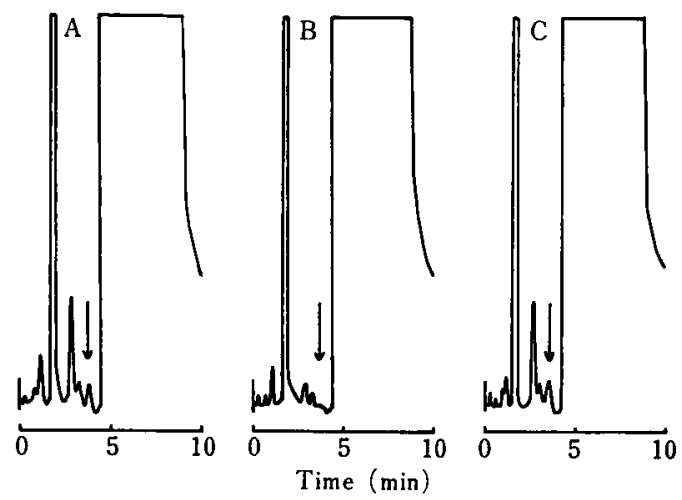

Fig. 4 Gas chromatograms of methyl iodide A; before GPC, B; GPC fraction 6-9, C; GPC fraction $10-20$

Arrows indicate retention time of methyl iodide.

行った。これより，MC の全回收率は $97 \%$ でフラクシ ヨン 7〜9をとると 90\% の MC が回収された。

次に Fig. 4 に MC を含まないみかんの缶詰 $5 \mathrm{~g}$ か らの抽出溶液をそのまま定量した場合 (A) と，GPCに よりフラクション 7〜9を取った場合 (B), 及びフラク ション 10〜20を取った場合（C）の GCチャートを示 した。図中，矢印はヨウ化メチルの保持時間を示す。A のヨウ化メチルと同一位置に見られるピークは，Bでは ほとんど見られず，フラクション 10〜20のCに見ら れることから， GPC により MC と妨害物の分離が可能 であることが明らかとなった。

\section{4. 添加回収実験}

$\mathrm{MC}$ を含まないみかんの午詰に MCを $0.001 \%, 0.1$ $\%$ 添加して回収実験を行った。回収率は $0.01 \%$ 添加で
やや低く $62.0 \%$ であったが，0.1\%添加で $86.2 \%$ と良 好であった。

\section{5. 市販みかん午詰中の MC 含有量の測定}

市場より購入したみかんの色詰 11 榆体中の MC 含有 量を測定したところ，MC 添加の表示のない7つの検体 でもガスクロマトグラム上㪣小なピークが見られた。そ の量は MC 相当量で平均 $8 \pm 1.5 \mathrm{ppm}$ とほぼ均一に愉 出されることから，GPCでむ除去できないメトキシル 基含有成分と思われ，測定值はこの值を差し引いて示す ことにした。MC 添加と表示のあった 4 検体中， 3 検体 から MC が $0.0015 \% ， 0.0012 \% ， 0.0008 \%$ 検出された が残りの 1 検体から検出されなかった。

要約

（1） GPC により妨害物質を除去することにより， み かんの缶詰中の MC 定量が可能となった。

（2）みかんの午詰に MC 0.1\% 添加したところ回収率 は 86\%と良好であった。

(3) 市販のみかんの年詰では 11 梚体中 3 娭体に $0.0008 \sim 0.0015 \%$ のC が検出された。

$$
\text { 文献 }
$$

1) 食品添加物公定書解説書編集委員会編：第四版食 品添加物公定書解説書 (淘川蓄占, 東京), p. B -940 (1979).

2）厚生省環境衛生局食品化学課編：食品中の食品添 加物分析法 (請談社, 東京), p. 550 (1982).

3) Schmolk, W., Mergenthaler, E.: Z. Lebensm. Unters. Forsch., 152, 263 (1973).

4) 日本生化学会編：生化学実験講座第 4 巻, 楛質の 化学:（下）(東京化学同人,東京), p. 370 (1976).

(昭和 59 年 7 月 17 日受理) 